\title{
CE Marking of Structural Timber: the European Standardization Framework and its Effects on Italian Manufacturers
}

\section{CE oznaka strukturne građe: Europski okvir normizacije i njegovi učinci na talijanske proizvođače}

\author{
Professional paper • Stručni rad \\ Received-prispjelo: 15. 3. 2012. \\ Accepted-prihvaćeno: 15. 11. 2012. \\ UDK: $630 * 75 ; 630 * 833$ \\ doi:10.5552/drind.2013.1214
}

\begin{abstract}
Structural timber has been used for centuries in construction and represents a traditional building component in many countries of the European Union. Nowadays, the interest in its use has been renewed due to several factors such as: ease of processing, relative lightness, mechanical performance, sustainability and decorative appearance. On March 2011, the European Parliament adopted the Regulation (EU) No. 305/2011 (known as CPR), laying down harmonized conditions for the marketing of construction products. According to CPR's dispositions, since January $1^{\text {st }} 2012$ CE marking of structural solid timber has been mandatory. While on one hand for the building sector enterprises this implies remarkable challenges, on the other hand it will allow a better valorization of structural timber. In this context, the present work illustrates the European standardization framework for CE marking of structural timber, particularly with respect to the visual grading method applicable to solid wood products and to the Italian experience in adopting the new rules.
\end{abstract}

Keywords: structural timber, normative framework, CE marking, visual grading, machine grading

SAŽETAK • Strukturna se drvna građa stoljećima upotrebljava u graditeljstvu i čini tradicionalnu sastavnicu gradnje u mnogim zemljama Europske Unije. Danas nekoliko činitelja pridonosi obnovi zanimanja za uporabu strukturne drvne građe, među kojima su jednostavnost obrade, relativna lakoća, mehanička svojstva drva, obnovljivost i dekorativan izgled drvne građe. U ožujku 2011. godine Europski je parlament usvojio Uredbu EU No 305/2011 (poznatu kao CPR), kojom su usklađeni uvjeti za prodaju građevnih proizvoda. Prema dispozicijama CPR-a od 1. siječnja 2012, za strukturno masivno drvo obvezna je oznaka CE. Iako za poduzeća gradevnog sektora to podrazumijeva mnoge izazove, to će omogućiti i bolju valorizaciju strukturne građe. U tom kontekstu ovaj rad ilustrira Europski okvir normizacije za CE oznaku strukturne građe, s posebnim naglaskom na vizualnoj metodi ocjenjivanja kvalitete koja je primjenjiva za proizvode od masivnog drva, te sosvrtom na talijanska iskustva u usvajanju novih pravila.

Ključne riječi: strukturna građa, normativni okvir, oznaka CE, vizualno ocjenjivanje kvalitete, mehanizirano razvrstavanje

\footnotetext{
${ }^{1}$ Authors are assistant, research associate and associate professor at University of Torino, Department of Agricultural, Forestry and Food Sciences (DiSAFA), Torino, Italy.

Autori su asistent, znanstvenik i izvanredni profesor Sveučilišta u Torinu, Odjel za poljoprivredne, šumarske i prehrambene znanosti, Torino, Italija.
} 


\section{INTRODUCTION}

\section{UVOD}

Structural timber has been used for centuries in construction and represents a traditional building component in many countries of the European Union (Giordano, 1997; Moffet et al., 2003; Pryce, 2005). Nowadays, the interest in its use has been renewed due to several factors such as: ease of processing, relative lightness, good mechanical performance (particularly in terms of strength to weight ratio), sustainability, recyclability, decorative aspect, etc. (Anonymous, 2006; Kolb, 2008).

On March 2011 the European Parliament adopted the Regulation (EU) No. 305/2011 (CPR, acronym for Construction Products Regulation) repealing the Construction Products Directive 89/106/EEC (CPD) ${ }^{1}$. As stated by Article 1, the Regulation "[...] lays down conditions for the placing or making available on the market of construction products by establishing harmonized rules on how to express the performance of construction products in relation to their essential characteristics and on the use of CE marking on those products". As a construction product ${ }^{2}$, structural timber $^{3}$ (Figure 1) is subjected to CPR's dispositions. In particular since January $1^{\text {st }} 2012$, it can be placed on the market only if $\mathrm{CE}^{4}$ marked.

Through CE-marking, the manufacturer states that a specific product meets the essential requirements of the European legislation and assumes the corresponding responsibility. The product properties must be declared on the product itself, on the packaging or attached to the delivery documentation and a declaration of conformity must be delivered to the customer. As for the CE marking of structural timber, grading represents a fundamental factor, but grading system managing and product traceability are also relevant topics.

The implementation of a CE marking system also requires the involvement of a notified body to certify the attestation of conformity requirements. Furthermore, the notified body carries out an annual audit for verifying the manufacturer's capability to meet the different requirements.

The cost of the implementation of a CE marking system depends on company size and production volume. As a general rule it can be esteemed around 4,0006,000 euro for most of the small and medium enterprises producing structural timber, including the audit costs and the support of an external consultant.

CE marking obligation implies remarkable challenges for carpentry enterprises, nonetheless it represents a relevant step for increasing the reliability of structural timber. In this context, the present work aims to illustrate the European standardization framework

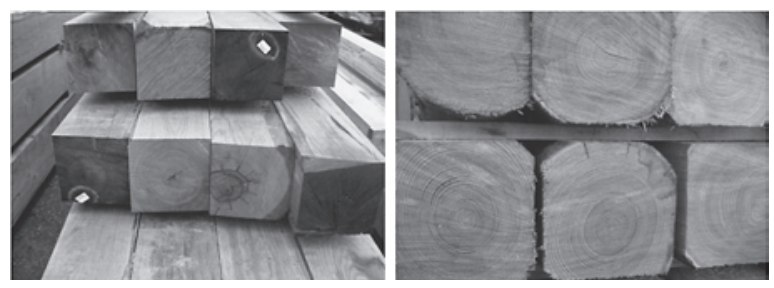

Figure 1 Rectangular (left) and irregular (right) cross section timber for structural use is subjected to CE marking obligation since January $1^{\text {st }} 2012$

Slika 1. Strukturna građe pravokutnoga (lijevo) i nepravilnoga (desno) poprečnog presjeka od 1. siječnja 2012. obvezno mora imati oznaku CE

for CE marking of structural timber, with particular respect to the visual grading method applicable to solid wood products. The current Italian situation is also reported in order to illustrate how the CE marking obligation interacts with the reality of an EU country. On the whole, the analysis of such a complex framework can be useful for the industrial and scientific communities of new countries acceding into EU.

\section{CE MARKING OF STRUCTURAL TIMBER: THE STANDARDIZATION FRAMEWORK 2. CE OZNAKA STRUKTURNE GRAĐE: OKVIR NORMIZACIJE}

Figure 2 shows the relations between different normative instruments regulating grading and $\mathrm{CE}$ marking of structural timber.

As shown, CE marking of structural timber arises from Regulation (EU) No. 305/2011 (CPR), which lays down the conditions for construction products marketing within the European Union. In particular, the CPR states the dispositions for $\mathrm{CE}$ marking according to the general principles set by Regulation (EC) No. 765/2008.

According to CPR Regulation, CE marking shall guarantee the conformity with harmonized standards when available. To this day, the latter list update has been published by the Official Journal of the European Union C 246, Volume 54, August $24^{\text {rd }} 2011$. For structural timber two options are envisaged on the basis of its rectangular and irregular cross section.

\subsection{Structural timber with rectangular cross section}

2.1. Strukturna građa pravokutnoga poprečnog presjeka

According to the above mentioned list, classification of structural timber with rectangular cross section shall be performed in accordance with EN 14081-1. This standard specifies the general requirements for visual and machine strength grading of structural timber with rectangular cross section shaped by sawing,

\footnotetext{
${ }^{1}$ CPR is currently into force, but several Articles will apply only from 1 July 2013. Therefore, even if the Construction Products Directive is already repealed, construction products manufactured in accordance with it before 1 July 2013 are compliant with the CPR.

${ }^{2} \mathrm{CPR}$ defines construction product as "any product or kit which is produced and placed on the market for incorporation in a permanent manner in construction works or parts thereof and the performance of which has an effect on the performance of the construction works with respect to the basic requirements for construction works".

${ }^{3}$ The present paper deals with structural solid timber, while for glue laminated timber other standards and requirements apply.

${ }^{4}$ Acronym for Conformité Europeénne.
} 


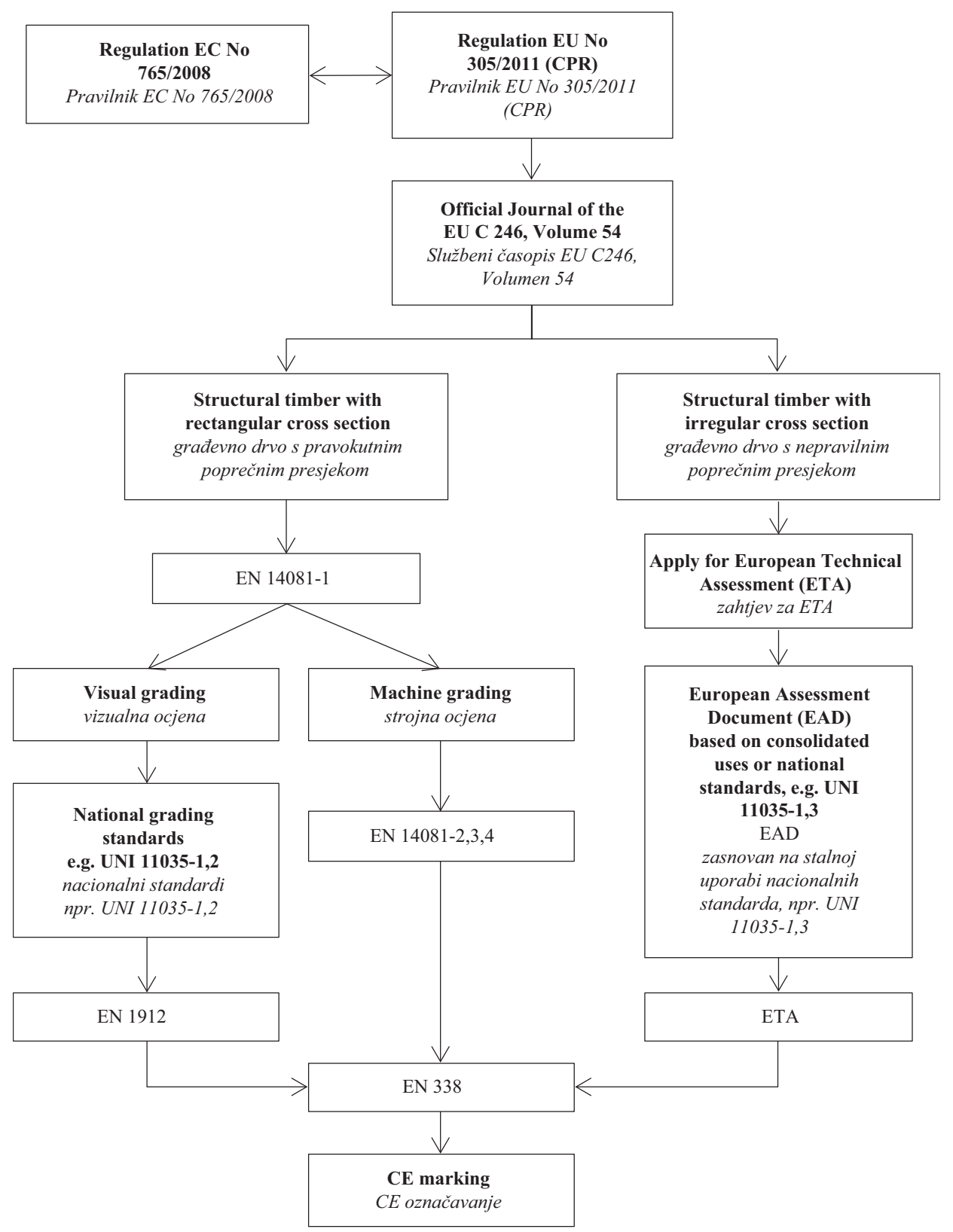

Figure 2 Scheme of standardization framework for CE marking of structural timber Slika 2. Shema okvira normizacije za CE oznaku strukturne građe

\begin{tabular}{|l|l|}
\hline \multicolumn{2}{|c|}{$\begin{array}{l}\text { Producer identification } \\
\text { Marking year } \\
\text { Identification number of FPC certificate number }\end{array}$} \\
\hline \multicolumn{2}{|c|}{ EN 14081-1 } \\
\hline Structural timber & \\
\hline Strength class & C24 (S10) \\
\hline Species code & Spruce (PCAB) \\
\hline Grading standard & EN 338 and DIN 4074-1 \\
\hline Reaction to fire & D-s2, d0 \\
\hline Durability class & 4 \\
\hline
\end{tabular}

Figure 3 Example of information to be reported on documentation accompanying CE marked structural timber Slika 3. Primjer informacije na dokumentaciji uz strukturnu građu koja nosi oznaku CE planing or other methods, and having deviations from the target sizes corresponding to EN 336.

\section{Visual strength grading}

Razvrstavanje prema vizualnoj procjeni čvrstoće

Nowadays several visual-grading national standards are in use in the European countries. This variability has arisen because structural timber assortments can differ in terms of species, geographic origin, dimensional requirements, uses, material quality, historic influences and traditions. Due to these specific parameters, it is impossible to lay down a single standard suitable for all Members of the European Union. For this reason EN 14081-1 just gives some basic principles to be followed by national standards when laying down requirements.

EN 1912 lists the various national standards that meet the EN 14081-1 requirements. According to EN 1912 , the choice of enforceable national standard de- 
Table 1 Example of correspondence between national grades and strength classes of the EN 338 (modified from Table 1 of EN 1912)

Tablica 1. Primjer usporedbe nacionalnog razvrstavanja i razreda čvrstoće prema EN 338 (modificirana tablica 1. iz EN 1912)

\begin{tabular}{|c|c|c|c|c|c|c|}
\hline $\begin{array}{l}\text { National } \\
\text { grade* } \\
\text { Nacionalni } \\
\text { razred }\end{array}$ & $\begin{array}{c}\text { Grading rule } \\
\text { publishing country } \\
\text { Zemlja koja je } \\
\text { objavila pravilo } \\
\text { razvrstavanja }\end{array}$ & $\begin{array}{c}\text { Species } \\
\text { commercial } \\
\text { name } \\
\text { Komercijalni } \\
\text { naziv vrste }\end{array}$ & $\begin{array}{c}\text { Source } \\
\text { Podrijetlo }\end{array}$ & $\begin{array}{l}\text { EN } 1912 \text { botanical } \\
\text { identification** } \\
\text { Botanička identifikac- } \\
\text { ija prema EN } 1912\end{array}$ & & $\begin{array}{c}\text { EN } 338 \text { Strength } \\
\text { class } \\
\text { Razred čvrstoće } \\
\text { prema EN } 338\end{array}$ \\
\hline ST-II & $\begin{array}{l}\text { France } \\
\text { Francuska }\end{array}$ & $\begin{array}{l}\text { Larch } \\
\text { ariš }\end{array}$ & $\begin{array}{l}\text { France } \\
\text { Francuska }\end{array}$ & 15 & $\rightarrow$ & \multirow{3}{*}{$\mathrm{C} 24$} \\
\hline S10 & $\begin{array}{l}\text { Germany, Austria } \\
\text { and Czech Republic } \\
\text { Njemačka, Austrija i } \\
\text { Češka Republika }\end{array}$ & $\begin{array}{l}\text { Larch } \\
\text { ariš }\end{array}$ & $\begin{array}{l}\text { Central, Northern } \\
\text { and Eastern Europe } \\
\text { Središnja, Sjeverna } i \\
\text { Istočna Europa }\end{array}$ & 15 & $\rightarrow$ & \\
\hline $\mathrm{T} 2$ & $\begin{array}{l}\text { Nordic countires } \\
\text { nordijske države }\end{array}$ & $\begin{array}{l}\text { Larch } \\
\text { ariš }\end{array}$ & $\begin{array}{l}\text { Northern and North } \\
\text { Eastern Europe } \\
\text { Sjeverna } i \\
\text { Sjeveroistočna } \\
\text { Europa }\end{array}$ & 15 & $\rightarrow$ & \\
\hline
\end{tabular}

* The grades listed in the table are specified in the Annex A of EN 1912, which reports grade, grading rule and grading rule publishing standard I razredi u tablici specificirani su u prilogu A norme EN 1912, koji prikazuje razrede, pravilo razvrstavanja i normu kojom je propisano pravilo razvrstavanja

** Tables 3 and 4 of EN 1912 report the correspondence between species botanical name and identification number / tablice 3. $i$ 4. norme EN 1912 prikazuju vezu između botaničkog naziva vrste drva i identifikacijskog broja

pends on species and provenance of the wood constituting the structural element to be graded. For instance, beams made of larch from France must be graded using the French standard NF B 52-001, while beams made of beech from Germany with DIN 4074-1.

The visual grading procedure is similar for the various national standards and basically states which characteristics (knots, grain slope, etc.) must be assessed and the limit values for their acceptance, so that a timber element can be assigned to a certain grade.

Once the grade is assigned, the EN 1912 allows finding the correspondence between the national grade and the harmonized strength class included in the standard EN 338. In detail, EN 1912 takes into account a combination of three factors (wood species, geographical origin and national grade) to individuate the correspondent strength class of EN 338 (Table 1).

The system of strength classes codified by EN 338 applies both to softwood and hardwood structural timber. EN 338 reports the characteristic values ${ }^{5}$ of resistance, stiffness and density for each strength class (Table 2).

Furthermore, EN 338 indicates the rules for the allocation of a timber population ${ }^{6}$ to a strength class. Firstly, characteristic values of bending strength, modulus of elasticity and density shall be determined in accordance with EN 384. Then, a timber population may be assigned to a certain strength class if its characteristic values of bending strength and density equal or exceed the values given for that class and if its characteristic mean Modulus of Elasticity in bending equals or exceeds $95 \%$ of the value given for that class.

\section{Machine strength grading \\ Mehanizirano razvrstavanje}

According to the physical laws of materials elasticity (Pellerin and Ross, 2002; Anonymous, 2011), instruments for non-destructive machine grading of structural timber exploit dynamic methods to evaluate the behavior of wood subjected to different types of stress.

Some instruments use natural or inducted, longitudinal or transversal, vibrations produced by stressing a wood element in different ways. In these cases the modulus of elasticity of a timber element is determined by measuring the oscillation extent.

Another possibility is offered by the analysis of wave propagation time inside wood: sonic or ultrasonic waves (the latter typically between 10 and $60 \mathrm{MHz}$ ) are transmitted to the end of the element (for instance by impact or using a piezoelectric drill emitting ultrasounds). Induced signals are received by a transducer placed on the other end of the element. Measuring the time elapsed between the impulse start and stop allows calculating the ratio between time and length of the covered distance, determining the propagation speed inside wood. Then, on the basis of wood density, by means of simple formulae, it is possible to calculate its dynamic modulus of elasticity.

It should be noted that strength classes of EN 338 report characteristic values for static elastic modulus determined by bending strength tests performed on elements in use dimensions. Therefore, when adopting a machine grading method, a correlation between dynamic and elastic modulus must be established in order to determine the correspondent EN 338 strength class for

\footnotetext{
${ }^{5}$ A characteristic value is "Generally a value that corresponds to a fractile of the statistical distribution of a timber property. For strength properties, modulus of elasticity and density, the fractile is the 5-percentile. For modulus of elasticity, the mean value is also a characteristic value", as reported by EN 384.

${ }^{6}$ Timber for which the characteristic values are relevant. The timber population is defined by parameters such as species or species grouping (combination of species), source and strength grade.
} 
Table 2 Example of characteristic values of C27 and D35 strength classes reported in the EN 338 (modified from Table 1 of EN 338)

Tablica 2. Primjer karakterisitčnih vrijednosti razreda čvrtoće C27 i D35 obuhvaćenih normom EN 338 (modificirana tablica 1. norme EN 338)

\begin{tabular}{|c|c|c|}
\hline & \multicolumn{2}{|c|}{$\begin{array}{l}\text { Strength classes } \\
\text { Razredi čvrstoće }\end{array}$} \\
\hline & $\begin{array}{l}\text { Softwood species } \\
\text { Meke vrste drva }\end{array}$ & $\begin{array}{c}\text { Hardwood species } \\
\text { Tvrde vrste drva } \\
\end{array}$ \\
\hline & $\mathrm{C} 27$ & D35 \\
\hline \multicolumn{3}{|l|}{ Strength properties, $\mathbf{N} / \mathbf{m m}^{2}$ / Čvrstoća, $N / \mathrm{mm}^{2}$} \\
\hline Bending / savijanje & 27 & 35 \\
\hline Tension parallel / vlačna čvrstoća, paralelno & 16 & 21 \\
\hline Tension perpendicular / vlačna čvrstoća, okomito & 0.4 & 0.6 \\
\hline Compression parallel / tlačna čvrstoća, paralelno & 22 & 25 \\
\hline Compression perpendicular / tlačna čvrstoća, okomito & 2.6 & 8.1 \\
\hline Shear/smicanje & 4.0 & 4.0 \\
\hline \multicolumn{3}{|l|}{ Stiffness properties, $\mathbf{k N} / \mathbf{m m}^{2} /$ Krutost, $\mathrm{kN} / \mathrm{mm}^{2}$} \\
\hline Mean Modulus of Elasticity parallel / prosječni modul elastičnosti, paralelno & 11.5 & 12 \\
\hline $5 \%$ Modulus of Elasticity parallel / $5 \%$ modul elastičnosti, paralelno & 7.7 & 10.1 \\
\hline Mean Modulus of Elasticity perpendicular / prosječni modul elastičnosti okomito & 0.38 & 0.80 \\
\hline Mean shear modulus / prosječni modul smicanja & 0.72 & 0.75 \\
\hline \multicolumn{3}{|l|}{ Density, $\mathbf{k g} / \mathrm{m}^{3} /$ gustoća, $\mathrm{kg} / \mathrm{m}^{3}$} \\
\hline $5 \%$ Density / $5 \%$ gustoća & 370 & 540 \\
\hline Mean density / prosječna gustoća & 450 & 650 \\
\hline
\end{tabular}

the same wood material. Hence, machine grading instruments require initial tests for establishing a correlation between their outputs and each type of graded wood.

In short, nowadays two machine grading systems are commonly used: output controlled and machine controlled. Both systems require a visual override inspection for evaluating the strength-reducing characteristics that are not automatically sensed by the machine. Apart from this common aspect, they are suited for different applications.

The output-controlled system is suitable for sawmill grading limited sizes, species and grades and working in repeated production runs of around one shift. This allows controlling the output of the system by testing specimens from the daily production. Together with statistical procedures, test results are used to monitor and adjust the machine settings.

On the other side, the machine controlled system is suited when, due to the large number of sizes, species and grades, it is not possible to perform the above mentioned daily tests. This system requires a strict control of the machine and remarkable research efforts aimed at determining the right settings.

As illustrated in Figure 2, machine grading must be performed according to EN 14081 Part 1, which specifies the general requirements, and to Parts 2, 3 and 4, which respectively lay down the additional requirements for initial type testing, for factory production control and the grading settings for machine controlled systems.

\subsection{Structural timber with irregular cross section 2.2. Strukturna građa nepravilnoga poprečnog presjeka}

To this day, timber elements with irregular section have been considered neither in the EN 14081-1 nor in other harmonized standards. Such a situation is envisaged by CPR, which prescribes the possibility of placing the CE marking on these products provided they have received a European Technical Assessment (ETA). This includes the declaration of product performance (by levels, classes or in a descriptive manner) for its intended use. Furthermore, it specifies the technical details necessary for the implementation of the system of assessment and verification of performance constancy. The procedure for obtaining an ETA is described in CPR's Annex II and can be summarized in three main steps.

Firstly, the manufacturer who wants to obtain an ETA, must apply to a Technical Assessment Body (TAB), a body designated by Member States. In particular, he must submit a technical file describing the product, its intended use and giving details of the factory production control (FPC).

Secondly, accepting the above request, the organization of TABs draws up and adopts a specific European Assessment Document (EAD). It contains, at least, a general description of the construction product, the list of its essential characteristics, methods and criteria for assessing the product performance. On the basis of the adopted EAD, the responsible TAB issues the relative ETA; starting from this point, the manufacturer can place the $\mathrm{CE}$ marking on its product according to ETA prescriptions.

It should be underlined that obtaining an ETA can require a period of a year and that it costs tens of thousands euro. Therefore, in order to share the costs, ETAs are often required by enterprises grouped in a consortium.

\section{THE ITALIAN CONTEXT 3. TALIJANSKI OKRUŽENJE}

The CE marking obligation for structural timber has determined several rebounds on the Italian wood 
Table 3 Italian species and grades with their corresponding harmonized strength classes to be included in the next draft of EN 1912

Tablica 3. Talijanske vrste drva i razredi u usporedbi s ujednačenim razredima čvrstoće koje bi trebale biti uvrštene u sljedeći tekst norme EN 1912

\begin{tabular}{|c|c|c|c|c|c|c|}
\hline $\begin{array}{l}\text { EN } 338 \\
\text { strength } \\
\text { class } \\
\text { Razredi } \\
\text { čvrstoće }\end{array}$ & $\begin{array}{l}\text { Italian grading } \\
\text { rule } \\
\text { Talijansko } \\
\text { pravilo } \\
\text { razvrstavanja } \\
\end{array}$ & \begin{tabular}{c|} 
Italian \\
national grade \\
Talijanski \\
nacionalni \\
razred \\
\end{tabular} & $\begin{array}{c}\text { Species commercial } \\
\text { name } \\
\text { Komercijalni naziv } \\
\text { vrste }\end{array}$ & $\begin{array}{c}\text { Source } \\
\text { Podrijetlo }\end{array}$ & $\begin{array}{c}\text { EN } 1912 \\
\text { Botanical } \\
\text { identification } \\
\text { Botanička } \\
\text { identifikacija }\end{array}$ & $\begin{array}{l}\text { Comments } \\
\text { Komentari }\end{array}$ \\
\hline $\mathrm{C} 30$ & UNI 11035-1,2 & S1 & $\begin{array}{l}\text { Douglas fir } \\
\text { duglazija }\end{array}$ & $\begin{array}{l}\text { Italy } \\
\text { Italija }\end{array}$ & 54 & $\begin{array}{c}\text { Maximum width and } \\
\text { thickness } 100 \mathrm{~mm} \\
\text { najveća širina i debljina } \\
100 \mathrm{~mm}\end{array}$ \\
\hline $\mathrm{C} 24$ & UNI 11035-1,2 & $\mathrm{S} 2$ and better & $\begin{array}{l}\text { Corsican pine } \\
\text { korzikanski bor }\end{array}$ & $\begin{array}{c}\text { Italy } \\
\text { Italija }\end{array}$ & 39 & - \\
\hline $\mathrm{C} 24$ & UNI 11035-1,2 & S2 and better & $\begin{array}{l}\text { Spruce\&fir } \\
\text { smreka/jela }\end{array}$ & $\begin{array}{c}\text { Italy } \\
\text { Italija }\end{array}$ & 1,22 & - \\
\hline $\mathrm{C} 22$ & UNI 11035-1,2 & S2 and better & $\begin{array}{c}\text { Larch } \\
\text { arišs }\end{array}$ & $\begin{array}{c}\text { Italy } \\
\text { Italija }\end{array}$ & 15 & - \\
\hline $\mathrm{C} 22$ & UNI 11035-1,2 & $\mathrm{S} 2$ and better & $\begin{array}{c}\text { Douglas fir } \\
\text { duglazija }\end{array}$ & $\begin{array}{l}\text { Italy } \\
\text { Italija }\end{array}$ & 54 & - \\
\hline $\mathrm{C} 18$ & UNI 11035-1,2 & S3 & $\begin{array}{l}\text { Larch } \\
\text { ariš }\end{array}$ & $\begin{array}{l}\text { Italy } \\
\text { Italija }\end{array}$ & 15 & - \\
\hline $\mathrm{C} 18$ & UNI 11035-1,2 & $\mathrm{S} 3$ & $\begin{array}{l}\text { Spruce\&fir } \\
\text { smreka/jela }\end{array}$ & $\begin{array}{c}\text { Italy } \\
\text { Italija }\end{array}$ & 1,22 & - \\
\hline $\mathrm{C} 14$ & UNI 11035-1,2 & $\mathrm{S} 3$ & $\begin{array}{l}\text { Corsican pine } \\
\text { korzikanski bor }\end{array}$ & $\begin{array}{l}\text { Italy } \\
\text { Italija }\end{array}$ & 39 & - \\
\hline D24 & UNI 11035-1,2 & $\mathrm{S}$ & $\begin{array}{l}\text { Sweet chestnut } \\
\text { kesten }\end{array}$ & $\begin{array}{l}\text { Italy } \\
\text { Italija }\end{array}$ & 79 & $\begin{array}{l}\text { Maximum thickness } 100 \\
\text { mm } \\
\text { najveća debljina } 100 \mathrm{~mm}\end{array}$ \\
\hline
\end{tabular}

sector. Reflecting the European standardization framework, the implications are different for structural timber with rectangular or irregular cross section.

The Italian national standard for visual grading of structural timber with rectangular cross section is the UNI 11035-1 and 2. The first part brings terminology and measurement of the characteristics, while the second part sets the rules for visual strength grading.

The inclusion of these standard into EN 1912 allows the grading and CE marking of structural Italian timber of several species, i.e. Norway spruce, silver fir, larch, Douglas fir, Corsican pine and sweet chestnut (Table 3).

Nonetheless, at the moment the species and grades to be included in the EN 1912 do not fully represent the production and potential of the Italian timber sector. Therefore, different Italian organizations and research bodies ${ }^{7}$ are carrying out further characterization activities in order to include higher strength classes for the Italian timber in the EN 1912. This will enable a better valorization of the national timber resources (Brunetti et al., 2011).

With respect to the structural timber with irregular cross section, it should be underlined that it boasts a long tradition in the Italian architecture (Giordano, 1997). In carpentry, this timber is used in the form of two main assortments:

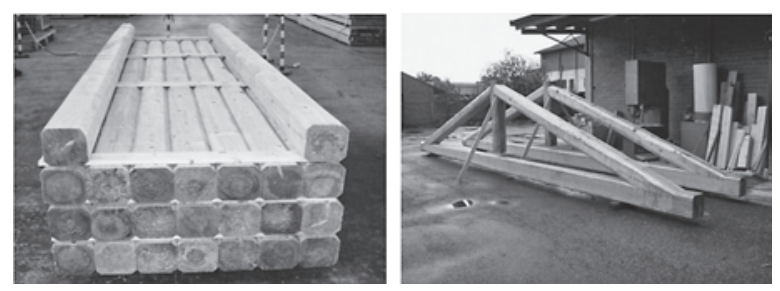

Figure 4 "Uso fiume" spruce beams (left) and trusses realized by assembling "Uso Fiume" larch beams (right) Slika 4. Smrekove grede Uso fiume (lijevo) i rešetka sastavljena od arišovih greda Uso fiume (desno)

- "Uso Fiume" (UF) beams: produced by parallel sawing of the log on four faces. They present wanes on their whole length, while their cross section is constant from end to end.

- "Uso Trieste" (UT) beams: produced by sawing of the log on four faces following its natural taper. They present wanes on their whole length, while their cross section gets narrow from end to end.

In order to valorize these assortments, in Italy the "Quality Consortium for Uso Fiume and Trieste beams" has been recently founded, and it currently consists of ten manufacturers located in the north-east of the country. The Consortium applied for an ETA in order to certify its products basing on the national standard UNI 11035-3. ETA was issued on June $24^{\text {rd }} 2011$ and therefore affiliated

\footnotetext{
7 The main organizations and research Bodies involved in these researches are the National Research Council, Federlegno-arredo and several Italian Universities.
} 
manufacturers are now able to place CE marking on their beams made of Norway spruce or silver fir.

Similarly, "Consorzio Servizi Legno Sughero Chestnut Uso Fiume Technical Committee" applied for an ETA for certifying UF chestnut beams. ETA was recently issued and now these products can be CE marked by manufacturers affiliated to the Consortium. Further activities are also in progress aimed at determining the characteristics values of Italian larch timber, in order to obtain a specific ETA for UF beams made of this species.

Finally, some portable instruments are currently undergoing a certification process for machine grading of Italian timber (Nocetti et. al., 2010). Once certified, their effective diffusion among the carpentry enterprises will be related both to their efficiency and cost. In fact, with few exceptions, the Italian carpentry enterprises are mainly family-owned business belonging to the group of small and micro enterprises ${ }^{8}$ (Anonymous, 2009), and grading machines could result too expensive in relation to their financial resources.

\section{CONCLUSIONS}

\section{ZAKLJUČCI}

The obligation of CE marking for solid wood structural timber entered into force on January $1^{\text {st }} 2012$. On one side, this represents a challenge for carpentry enterprises, in particular for the micro and small-sized enterprises; on the other side, it will allow the valorization of structural timber in its different forms, including the most traditional ones, which in the last period suffered the competition of engineered materials.

In fact, in order to be competitive with other construction products, nowadays structural timber should guarantee certified performance and specific moisture content. By means of computer numerical control (CNC) machines, pre-cut roof frames can be supplied, thus saving working time and installation costs.

With respect to Italy, the research efforts performed in the last several years make now possible $\mathrm{CE}$ marking of structural timber with rectangular or irregular cross section of different species coming from the national forests. Although this is of vital importance for the Italian carpentry enterprises, other issues are still open, such as the CE marking of Uso Fiume beams produced using wood coming from foreign countries.

On the whole, the recent introduction of $\mathrm{CE}$ marking obligation generated a wide scenario still in rapid evolution: several researches are in progress in order to enlarge the range of certifiable Italian structural timber, both in terms of strength classes and wooden species; the efficiency of small and micro enterprises in meeting the requirements of CE marking is still to be verified; the diffusion of machine grading instruments requires an adequate promotion activity.
Hopefully, the whole of these factors will contribute to move the Italian carpentry sector to improve the dynamics and competitiveness on the market.

\section{REFERENCES \\ 5. LITERATURA}

1. Brunetti, M.; Cerullo, S.; Lucchetti, M.; Nocetti, M.; Togni, M., 2011: Italian structural timber enters into Europe. Technical-normative situation for assortments with rectangular cross section (In Italian). Arealegno 56(11): 52-55.

2. Giordano, G., 1997: Wood anthology (in Italian). Vol. I. Reggio Emilia, Consorzio LEGNOLEGNO.

3. Kolb, J., 2008: Systems in timber engineering. Germany, Lignum DGhF.

4. Nocetti, M.; Bacher, M.; Brunetti, M.; Crivellaro, A.; Van de Kuilen, JW. G., 2010: Machine grading of Italian structural timber: preliminary results on different wood species. WCTE 2010 - 11th World Conference on Timber Engineering, Riva del Garda.

5. Moffet, M.; Fazio, M.W.; Wodehouse, L., 2003: A world history of architecture. London, Laurence King Publishing.

6. Pryce, W., 2005: Architecture in wood: a world history. London, Thames\&Hudson.

7. Pellerin, R.F.; Ross, R.J., 2002: Nondestructive evaluation of wood. Madison, Forest Products Society

8. Anonymous, 2011: 17th International nondestructive testing and evaluation of wood symposium - Proceedings. Sopron, University of West Hungary.

9. Anonymous, 2009: Inter-Bois Project, 2009. White book on transalpine forest-wood chain. Torino, Regione Piemonte.

10. Anonymous, 2006: Tackle climate change: use wood. Brussels, CEI-Bois.

11. COMMISSION RECOMMENDATION of 6 May 2003 concerning the definition of micro, small and mediumsized enterprises.

12. EN 336:2003 Structural timber - Sizes, permitted deviations.

13. EN 338:2009 Structural timber - Strength classes.

14. EN 384:2010 Structural timber - Determination of characteristic values of mechanical properties and density.

15. EN 408:2010 Timber structures - Structural timber and glued laminated timber - Determination of some physical and mechanical properties.

16. EN 1912:2012 Structural timber - Strength classes - Assignment of visual grades and species.

17. EN 14081-1:2005+A1:2011 Timber structures - Strength graded structural timber with rectangular cross section Part 1: General requirements.

18. EN 14081-2:2010 Timber structures - Strength graded structural timber with rectangular cross section - Part 2: Machine grading; additional requirements for initial type testing.

19. EN 14081-3:2005 Timber structures - Strength graded structural timber with rectangular cross section - Part 3: Machine grading; additional requirements for factory production control.

20. EN 14081-4:2009 Timber structures - Strength graded structural timber with rectangular cross section - Part 4 :

\footnotetext{
${ }^{8}$ According to the Recommendation of the European Commission of May 6 2003, a small enterprise is defined as "an enterprise which employs fewer than 50 persons and whose annual turnover and/or annual balance sheet total does not exceed 10 million $\epsilon^{\prime \prime}$; microenterprise is defined as "an enterprise which employs fewer than 10 persons and whose annual turnover and/or annual balance sheet total does not exceed 2 million $€$ ".
} 
Negro, Cremonini, Zanuttini: CE Marking of Structural Timber: the European...

Machine grading - Grading machine settings for machine controlled systems.

21. DIN4074-1 Ausgabe 2008,12 Sortierung von Holznach der Tragfähigkeit, Nadelschnittholz, 2003.

22. NF B 52-001 Août 2011 Règles d'utilisation du bois dans les constructions; Classement visuel pour employen structure pour les principales essences résineuses et feuillues.

23. UNI 11035-1:2010 Legno strutturale - Classificazione a vista dei legnami secondo la resistenza meccanica - Parte 1: Terminologia e misurazione delle caratteristiche.

24. UNI 11035-2:2010 Legno strutturale - Classificazione a vista dei legnami secondo la resistenza meccanica - Parte 2: Regole per la classificazione a vista secondo la resistenza meccanica e valori caratteristici per tipi di legname strutturale.

25. UNI 11035-3:2010 Legno strutturale - Classificazione a vista dei legnami secondo la resistenza meccanica - Parte 3: Travi Uso Fiume e Uso Trieste.

26. REGULATION (EU) No 305/2011 of 9 March 2011 laying down harmonized conditions for the marketing of construction products and repealing Council Directive 89/106/EEC.

27. REGULATION (EC) No 765/2008 of 9 July 2008 setting out the requirements for accreditation and market surveillance relating to the marketing of products and repealing Regulation (EEC) No 339/93.

\section{Corresponding address:}

NEGRO FRANCESCO, Ph.D.

AGROSELVITER Department

University of Torino

Via Leonardo da Vinci 44

10095 Grugliasco (TO)

ITALY

E-mail: francesco.negro@unito.it 